\title{
Effect of Scientific Inquiry Learning Model Assisted by Mind Mapping on Science Process Skills Student
}

\author{
Tria Anggreini \\ PostGraduate Universitas Negeri Medan \\ Medan, Indonesia \\ Togi Tampubolon \\ PostGraduate Universitas Negeri Medan \\ Medan ,Indonesia \\ togitampubolon011@gmail.com
}

\author{
Wawan Bunawan \\ PostGraduate Universitas Negeri Medan \\ UniversitasNegeriMedan \\ Medan, Indonesia \\ wanbunawan@gmail.com
}

\section{Rajo Hasim Lubis \\ Medan, Indonesia}

rajohasimlbs@unimed.ac.id

\begin{abstract}
The purpose of this study was to analyze the science process skills and creative thinking of students who were taught by the scientific inquiry learning model using mind mapping. The study was conducted on the eighth-grade students of Tunas Harapan Private Middle School in Sayurmatinggi Village, Ujung Padang Learning Year 2018/2019. This type of research includes quasi-experimental, quasi-experimental research design with two groups pretest-posttest design. The research instrument used was essay-shaped test for science process skills and students' creative thinking abilities. The conclusions obtained are; (1) Students' physical science process skills with scientific inquiry learning using mind mapping are better than science process skills students use conventional models; (2) Science process skills of students in the group of creative thinking skills above the average are better than the creative thinking skills below the average; (3) In this study, creative thinking skills above the dominant average improve the science process skills of students in the scientific inquiry model using mind mapping rather than in conventional learning.
\end{abstract}

\section{Keywords-Scientific Inquiry, Mind Mapping, Science Process Skill}

\section{INTRODUCTION}

Based on the results of the preliminary study at Tunas Harapan Private Middle School, generally, science learning in schools still emphasizes results while the process is often ignored. The teacher once gave a question to test the cognitive abilities of students in science learning in class VIII, but the teacher had never given a test question that measured students' thinking skills, such as science process skills and the ability to think creatively. From reports on physics learning outcomes and interviews, it was found that science learning in these schools had been applied to student-centered learning. But teachers tend to emphasize mathematical equations in solving physical problems and not train students in science process skills. The achievement of student learning outcomes in science learning especially physics in some basic competencies is still low, with the presence of several students who have below standard completeness. Teachers have not created interactive, inspirational, fun and challenging learning activities for their students, and provide sufficient space for initiatives, creativity, and independence in accordance with the talents, interests, and physical development and psychology of students. The application of scientific inquiry learning is expected that students are more interested and can improve science process skills and students' creative thinking skills about the material presented so that the learning outcomes obtained by students also increase. Required learning models that facilitate students to be active in learning using scientific inquiry learning models.

According to Chew [1], inquiry-based learning in science can construct knowledge and investigative and reflective attitudes with empirical techniques as scientists. Science learning with the scientific inquiry model is significantly better than conventional learning [2]. In light material that is close to everyday life, a learning model is needed based on everyday problems. One such model is the scientific inquiry learning model. For light material, the process of shadow formation can be observed by students. Thus, learning on light material can be done through direct investigations. Investigation can be in the form of solving problems in everyday life related to light. Hopefully, learning light material with the scientific inquiry model can improve students' science process skills. physics science process skills students use scientific inquiry learning is better than science process skills students use conventional learning models.In light learning with the scientific inquiry model students carry out activities that involve science process skills. Students who have the ability to process high science will easily carry out investigations. All inquiry scientific activities involve process skills which include basic process skills, measurement and calculation skills, experimental planning skills and skills in processing and presenting data.

Learning activities are said to be successful can be seen from the assessment carried out on students. The assessment used in learning activities with the scientific inquiry learning model must be able to measure the intended skills. Therefore, the instrument of science process skills assessment is used using the scientific inquiry model. Science process skills are the ability of students to apply scientific methods in understanding, developing, and discovering science. 
The ability to think creatively on physics subjects is a very important ability for students to solve problems that are being faced. Students' creative thinking ability can be interpreted as the ability to think based on available data and information, finding many possible answers operationally.

Creativity as a multi-dimensional construct consists of various dimensions, namely cognitive, affective, and psychomotor dimensions. The ability to think creatively, be creative and creative skills is a unity that must be possessed by students who have creativity. Research conducted by [3] explains that there are three kinds of creativity, including product creativity, people's creativity, and brain creativity. Creative dimensions and kinds of creativity are influenced by several factors that must be considered, including training, individual differences, intelligence possessed, psychopathology or mental, group or team, and social environment.

\section{RESEARCH METHOD}

This research will be carried out on the eighth-grade students of Tunas Harapan Private Middle School in Sayurmatinggi Village, Ujung Padang. Sampling is done by cluster random sampling where each class has the same opportunity to become a research sample. One class is used as an experimental class, namely the class taught by the scientific inquiry learning model and another class is used as the control class, namely the class taught by conventional learning models.

This type of research included quasi-experiment with the design of two group pretest-posttest. Data collection in this study using research instruments, namely tests of science process skills and students' creative thinking abilities. Data collection is carried out in two stages, the first stage is collecting data on science process skills and the second stage collecting data on the ability to think creatively. The research instrument used was an essay-shaped test for science process skills and students' creative thinking abilities. The data analysis technique used is the Lilliefors test to test normality, the comparison test for variance to see homogeneity and t-test for hypothesis testing.

\section{RESULT AND DISCUSSION}

\section{A. Physics Science Process Skills Students Learned with} Scientific Models Inquiry Using Mind Mapping is Better Compared to Students Learning with Conventional Learning

The findings in this study show that the physics science process skills of students who were taught by the scientific inquiry model using mind mapping were better than conventional learning. This result is in line [4] concluded that the scientific inquiry learning model using mind mapping can improve the quality of physics learning and be more effective in improving students' science process skills compared to conventional learning. The same thing was also obtained by [5]. Furthermore, it was concluded that inquiry scientific learning models not only designed students' understanding but also their ability to understand and use multimodal representations and to produce better explanatory qualities. Fadillah[6] states that students' cognitive abilities in science process skills of students using the Conceptual Change-based Scientific Inquiry learning model are better than conventional learning models. According to Fatmawarni [7] inquiry-based hands-on learning activities can improve scientific attitudes and science process skills and contribute positively to student achievement in the fields of science, scientific literacy, and attitudes towards science. This proves that the learning model greatly influences students' science process skills. It also shows that the scientific inquiry model is better at improving student learning outcomes.

Significant results in this study are caused by learning with the scientific inquiry model involving students actively in understanding the concepts and principles of a material because the characteristics of this learning are in the form of submitting problems to students. Problems given can train students to develop high-level abilities of students. The intended ability is to familiarize students with creative thinking by exploring and expressing ideas and identifying problems that can be applied to solve problems given so that they teach students to learn independently. This is in line with Nurul [8] the scientific inquiry learning model is applied to academic inquiry, provides research techniques, develops problem solving skills, increases the level of reasoning, the level of critical thinking, develops the level of understanding, the scientific inquiry model plays a role in explaining abstract concepts of physics into more concrete so that it is easier for students to understand abstract concepts that have been experienced by students.

Scientific inquiry learning model can receive the attention of students to attend learning in class and students not only imagine abstractly about the concept of light material, but students can see directly the concepts of light material taught by the teacher because the subject matter can be packaged attractively so that the learning atmosphere becomes more fun indirectly and this affects the factors in the student, namely interest, attention and creative thinking skills of students to learn.

This is with the research conducted by Oktaviana [3] which states that there is a significant difference between the methods of conventional learning and scientific inquiry and learning towards learning outcomes, the control class that is taught with conventional learning, students tend to accept learning in one direction and are less confronted with problems which make students independent in developing their own understanding. In addition, the activity of exchanging ideas between students in the control class was less effective because in the learning process the teacher had more role in channeling knowledge.

\section{B. Students' Physical Science Process Skills in the Group of} Students with Above Average Creative Thinking Skills are better than the Group with Students with Creative Thinking Skills below Average

The results obtained in this study indicate that the physics science process skills of students in the group of students who have creative thinking skills above the average are better than the physics science process skills of students in 
the group of students who have creative thinking skills below average. This finding is in line with the results of the research conducted by Anggraini [9] which suggests that there is a positive influence of creative thinking skills on learning on student learning outcomes where learning outcomes achieved by students who have creative thinking skills are high (above average) more good compared to students who have low learning skills (below average). Furthermore, Rospita [10] states that there is a significant influence between creative thinking skills and learning achievement where the average value achieved by students who have high learning creative thinking skills is better than the average value of students whose learning creative thinking skills are low.

The increase in students' physical science process skills is caused by students who have creative thinking skills above the average creative thinking skills for learning, always active in class, dare to express their opinions, be able to respond to the problems they face and are persistent in solving problems so that it can produce high learning outcomes, in this case, students' physical science process skills. Unlike the case with students who have creative thinking skills below the average students tend to not care about the problems faced and do not have the desire to know and remain silent do not want to express opinions on a new experience and less diligent and persistent in solving a problem. When they find difficulties in solving a problem, feeling hopeless and giving up quickly is something that is felt by students, as a result it is difficult to carry out learning activities that require high activity and drain thoughts. This is in line with [11] stating that students who have low learning creative thinking skills are less diligent and persistent in solving a problem when they find difficulties in solving a problem, despair, and quick surrender are things that are felt by students. In addition students also do not have the desire to investigate and find solutions to a problem given, as a result students do not like difficult and difficult tasks. This can be seen in learning activities, students with creative thinking skills below average show low activity both in organizing, conducting investigations and presenting results and reports that have been carried out. These trends cause students with creative thinking skills below the average do not have the ability to analyze and synthesize the problems faced. This is in line with Suryanti [12] research study saying that to improve students' science process skills.

\section{There is an interaction between the scientific inquiry model and creative thinking skills towards students' science process skills}

The interaction referred to in this case is the conventional scientific inquiry and learning model at the level of students' creative learning skills which are better used. Based on the results of hypothesis testing for interactions between the scientific inquiry model and creative thinking skills towards physics science process skills students show that there is an interaction between the scientific inquiry model and creative thinking skills towards students' physical science process skills. This is in line with Anggraini [9] research study saying that to improve students' science process skills. The difference with previous researchers is that in this study students 'activities are more narrowed on students' creative thinking skills.

The existence of interactions in this study is due to students 'creative thinking skills play an important role in improving students' physical science process skills optimally. The inquiry scientific model has a better effect on learning creative thinking skills above average than creative thinking skills learning below average. This is because the scientific inquiry model with learning creative thinking skills is above the average students are invited to criticize starting from the problem, collect, and analyze and conclude the answers to the problems, so that students are actively involved directly during the learning process, encouraging students at the level of thinking skills higher creativity and more meaningful learning.

Conventional learning is learning that tends to be teacher-centered, where learning activities are fully held by the teacher in order to achieve all subject matter so students who are basically active in the classroom experience increased learning outcomes, while inactive students only sit on the knowledge conveyed by the teacher. Therefore increasing student physics learning outcomes obtained by students was not significant when viewed from the average value, to achieve better learning outcomes, then each student must have creative thinking skills, learning above average so students who diligently study, responsive in facing difficulties, attention is more focused on the material being taught.

\section{IV.CONCLUSION}

Based on the results of the study concluded that the physics science process skills of students with scientific inquiry learning using mind mapping are better than the science process skills students use conventional models, science process skills of students in the creative thinking skills group above the average is better than the creative thinking skills below the average and creative thinking skills above the dominant average improve science process skills students in the scientific inquiry model use mind mapping rather than conventional learning.

\section{REFERENCES}

[1] Chew, Charles. 2011. Professional Development of Inservice Science Teachers in.

[2] Sumarni, (2017), Pengaruh Model Pembelajaran dan Inkuiri Terbimbing Terhadap hasil Belajar Kognitif Peserta Didik Di SMA Negeri 01 Manokwari, JurnalNalar Pendidikan, 5(1), 21-30.

[3] Oktaviana, S, 2015, Pengembangan Bahan Ajar Fisika Berbasis Guide Inquiry untuk Meningkatkan Berpikir Kreatif Siswa. Skripsi, Semarang: FMIPA UniversitasNegeri Semarang.

[4] Akhyar. M. Lubis, (2017), Analisis Model PembelajaranScientific Inquiry dan Kemampuan Berpikir Logis terhadap Keterampilan Proses Sains Siswa, dikfispascasarjanaunimed, 6(2), 70-75.

[5] Clara. Dian N.S., (2014), Analisis Model PembelajaranScientific Inquiry dan Sikap Ilmiah terhadap Hasil Belajar Siswa pada Pelajaran Fisika, dikfispascasarjanaunimed, 3(2), 22-25. 
[6] Fadilah, A.S., Gardjito, \& J. Siburian. 2009. Analisis Kemampuan Berpikir Kreatif Siswa dalam Proses Belajar Biologi di Kelas XI IPA SMA 5 Kota Jambi. Skripsi. Jambi: FKIP Universitas Jambi.

[7] Fatmawarni, 2016, Pengaruh Model Pembelajaran Inkuiri Training Berbasis Kolaboratif dan Pemahaman Konsep Awal terhadap Keterampilan Proses Sains IPA Siswa SMP, Medan: Skripsi UNIMED Medan.

[8] Nurul Ain A.K Cibro, 2016, Efek Model Pembelajaran Inquiry Training dan Kemampuan Berpikir Kreatif terhadap Keterampilan Proses SainsSiswaMTs, Medan: Skripsi UNIMED Medan.

[9] Anggraini,Puji. Dini, (2015), Analisis Model PembelajaranScientific Inquiry dan Kemampuan Berpikir Kreatif terhadap Keterampilan Proses SainsSiswa, dikfispascasarjana unimed,4(2), 47-54

[10] Rospita, 2017, Efek Model Pembelajaran Scientific Inquiry dan Keterampilan Berpikir Kreatif terhadap Keterampilan Proses Sains Siswa, Medan: Skripsi UNIMED Medan.

[11] Suryani, 2017, Efek Model Pembelajaran Scientific Inquiry Menggunakan Mind Mapping dan Kemampuan Berpikir Kritis Terhadap Keterampilan Proses Sains Siswa Sekolah Menengah Atas, Jurnal Pendidikan Fisika, 6(2), 86-90.

[12] Suryanti, 2013, Peningkatan Kemampuan Berpikir Kreatif Siswa Melalui Model Pembelajaran Inkuiri Pada Mata Pelajaran Ilmu Pengetahuan Alam, JPGSD, 1(2), 1-14 